\title{
THE IMPACT OF READING COMPREHENSION ON MATHEMATICS WORD PROBLEM SOLVING
}

\author{
Rajmonda Kurshumlia ${ }^{1} \&$ Eda Vula ${ }^{2}$ \\ ${ }^{1}$ Doctoral Student, University of Prishtina/Faculty of Education (Kosovo) \\ ${ }^{2}$ Professor at the University of Prishtina/Faculty of Education (Kosovo)
}

\begin{abstract}
Word problem constitutes an important part of the mathematics curriculum of the elementary school. Different studies have argued that the understanding of the problem is the most difficult part for students, because of the lack of understanding of the 'keywords' used in the problem contexts. Thus, because the process of word problem solving is related to reading comprehension, as a most important factor in this study it was examined the impact of reading comprehension for improving student's skills for mathematics word problem-solving. Participants in the study were fifty-fourth-grade students and their teachers. The methodology of the study is the collaborative action research. The researchers (authors) have worked together with two class teachers and have used the Reciprocal Teaching method as an intervention for eight weeks aimed to improve the student's skills for reading comprehension. The Reciprocal Teaching method includes prediction, clarifying, questioning and summarizing strategies. The data collection instruments used in this study were teachers' reflections and pre and post-test. The results from this study show that the improvement of student's skills for reading comprehension has a positive impact on the improvement of student's skills for mathematics word problem-solving.
\end{abstract}

Keywords: Mathematical word problems, reading comprehension, reading strategies, reciprocal teaching.

\section{Introduction}

Studies have shown that the mathematics word problem-solving is of great importance for learning mathematics, but it is as well associated with highlighted difficulties by students (Jitendra, Griffin, Deatline-Buchman \& Sczesniak, 2007; Capraro, Capraro \& Rupley, 2012; Özsoy, Kuruyer, Çakiroglu, 2015; Zhu, 2015, Vula, Avdyli, Berisha, Saqipi, \& Elezi, 2017).

The word problems represent situations described by words that students should first translate into mathematics language and then present their solutions (Burns, 2007: 172). Mathematics word problem-solving are a complex cognitive activity that involves a number of processes and strategies. According to Zhu (2015), word problem solving represents a series of actions required by students during this process. It requires students high-level thinking rather than simply memorizing facts or practicing certain routine procedures. Even though, Daroczy, Wolska, Meurers, \& Nuerk, (2015) classifies word problems, as the most difficult and complex that students encounter during their mathematical development. The most common difficulties in mathematics word problem-solving are skills for reading comprehension of the contexts of the problem (Pearce et al., 2013). To accomplish mathematics problem solving, students need to understand, analyze, represent, execute and evaluate problems. Polya (1957) has proposed four steps to help students in solving mathematical word problems: understanding the problem, designing a plan, implementing the plan, and reviewing. On the other hand, Van Garderen (2004) states that the effective mathematics word problem solvers are able to understand the purpose of a problem. While according to Polya (1957) the first step in solving problems is the understanding the problem as one of the most important components of the process. Students need to understand the problem and not just understand it but they need to identify and examine the data before they start implementing algorithms. Therefore, comprehension of the verbal statements of the problem is essential (Polya, 1957: 6). Word problem solving is related with reading comprehension as an important factor that includes understanding the problem within linguistic complexity of the text (Vilenius-Tuohimaaa, Aunolab and Nurmib, 2008; Capraro et al, 2011; Özsoy,Kuruyer, Çakiroglu, 2015; Boonen, De Koning, Jolles \& Van der Schoot, 2016; Vula et al., 2017). Reading in mathematics requires to be achieved the correct 
mathematical understanding of words for developing and understanding problem solutions. 'Students need to understand the word problem to be able to solve it, not just simply to read it, they should be good readers. Good readers and good math word problem solvers have the ability to observe their understanding '(Capraro, et al., 2011). Achieving the meaning of written texts or sentences is one of the main pillars of developing the reading skills. However, the simple fact that children can read does not mean that they also can understand what they have read. Therefore, performance in word problem solving is closely related to reading comprehension performance (Vilenius-Tuohimaa et al., 2008; Özsoy, Kuruyer, Çakiroglu, 2015). Students should develop skills of good readers and use the reading comprehension strategies for understanding the mathematical content of word problems. Theoretical models and teaching strategies for solving word problems in mathematics proposed by many researchers are based on the use of reading comprehension as a tool for enhancing the level of achievement in solving this type of problems (Carparo et al., 2012; Jitendra et al., 2007).

Reciprocal Teaching is a method which includes reading comprehension strategies to help students to improve reading comprehension. Reciprocal teaching is characterized as a dialogue through which teachers and students work together to understand the text (Palinscsar \& Brown, 1986). This approach includes strategies: prediction, clarifying, questioning and summarizing. Each of the strategies of the reciprocal teaching method promotes both comprehensions of text and comprehension monitoring. When students make predictions, they hypothesize what the author will discuss next in the text. To do this successfully, they must activate the relevant background knowledge that they already possess. Clarifying is particularly important with students who have comprehension difficulties of the text they read. Question generating gives the students an opportunity to identify the kind of information that provides the substance for a good question and summarizing is an excellent tool for integrating the information presented in the text (Palincsar \& Brown, 1986).

The purpose of the study is to examine the impact of reading comprehension on mathematics word problem-solving. Firstly, it was important to see how reciprocal teaching can improve the reading comprehension and secondly, how this improvement has an impact on students' outcomes for solving the mathematics word problems.

\section{Method}

In this study, we chose to conduct collaborative action research. This approach focuses on empowering teachers in schools, improving teaching practices and the active involvement of teachers and students in teaching and learning activities. Thus, as researchers (authors) and two teachers collaboratively have planed the intervention in their classes. During the study through observation, review of student's work and reflection of teachers, it is possible to explore the dynamics, challenges and possible limitations.

The data collection instruments and techniques that have been used in this research are pre- and posttest with mathematical word problems and journals with teachers' reflections.

\subsection{Procedure}

The intervention method used in this study was the implementation of reading strategies of reciprocal teaching method, based on the reciprocal teaching method created by Palincsar \& Brown (1986). This method was implemented by reading comprehension strategies: predicting, clarifying, questioning and summarizing. Two teachers received the instructions from us as the researchers for the implementation of reading comprehension strategies in their classrooms with students in small groups. The instructions for the teachers were related to the use of the reading comprehension strategies of reciprocal teaching method: predicting, clarifying, questioning and summarizing. The reading strategies were introduced through whole class instruction and then in smaller groups to practice the strategies. The teachers went over the process making the strategies very clear and they worked with their students for implementation of reading comprehension strategies.

Predicting Teachers taught the students to make predictions for the text they read and to relate with their previous knowledge, students find the information, relate to the previous knowledge and predict what might be or what they have to do after.

Clarifying Students have to clarify the unclear words, keywords, and concepts, look up for the words and phrases that are not clear and try to clarify them.

Questioning Students generate questions about the reading text, they make questions, they lead the discussion with group members about the text they read.

Summarizing Summarize meaning of the text they read, including the main idea and the main request from the text (Palincsar \&Brown, 1986). 

students.

Teachers used those strategies with reading texts and with word problems to practice with their

Before the implementation of the intervention method, students were assessed with pretest for mathematics word problem solving and again after the implementation method they are assessed with post-test. The pretest and posttest (were the same) and they included five mathematical word problems.

The reading comprehension strategies are implemented during eight weeks and the two fourth grade teachers worked with their students in their classrooms during this time. Two teachers participated in the research with the researcher for changing their student's attitudes toward word problem-solving in mathematics and developing their teaching practices. My role as a researcher was to guide two teachers and to collaborate with them in this collaborative action research, we gave them the guidelines for the implementation method we work together in a whole process.

Figure 1. Examples of mathematics word problems from pre-test and posttest.

\begin{tabular}{|l|l|}
\hline $\begin{array}{l}\text { Në "Klubin e gjelbër" janë të regjistruar 276 fëmijë, } \\
\text { kurse në "Klubin e artit" } 105 \text { fëmijë më pak. Sa fëmijë } \\
\text { janë të regjistruar në të dy klubet? }\end{array}$ & $\begin{array}{l}\text { In the "Green Club" are registered 276 children, } \\
\text { whereas in the "Art Club" 105 children less. How } \\
\text { many children are registered in both clubs? }\end{array}$ \\
\hline $\begin{array}{l}\text { Andi vendosi në një album } 420 \text { fotografi që kishte bërë } \\
\text { gatë pushimeve. Ai vendosi } 7 \text { fotografi në një faqe të } \\
\text { albumit. Sa faqe të albumit mbushi Andi? }\end{array}$ & $\begin{array}{l}\text { Andy put on an album } 420 \text { photos he had taken } \\
\text { during the holidays. He placed } 7 \text { photos on an } \\
\text { album page. How many pages of the album did } \\
\text { Andi fill? }\end{array}$ \\
\hline $\begin{array}{l}\text { Në treg u shitën javën e parë 1249 kg fruta, kurse javën } \\
\text { e dytë } 80 \mathrm{~kg} \text { më shumë fruta. Sa kg fruta u shitën gjatë } \\
\text { dy javëve në treg? }\end{array}$ & $\begin{array}{l}\text { In the market were sold the first week 1249 kg of } \\
\text { fruit, while the second week } 80 \mathrm{~kg} \text { more fruit. How } \\
\text { many kilograms of fruit were sold over the two } \\
\text { weeks in the market? }\end{array}$ \\
\hline
\end{tabular}

\subsection{Instruments for data collection}

Data collection instruments were tests (pretest and posttest) and teacher's reflective diaries. Pretest was implemented before the intervention method and posttest after the intervention method in order to evaluate the impact of reading comprehension strategies for student's learning outcomes in word problem solving in mathematics, and semi-structured interviews with teachers in order to define the effectiveness of reading comprehension for improving student's skills for word problem solving in mathematics.

\subsection{Sample}

Participants of the study were fifty-fourth grade students, 26 students from class IVA and 24 students from class IVB (age 9-10 years old), IVA $(\mathrm{M}=9.6, \mathrm{SD}=0.494)$ and IV $\mathrm{B}(\mathrm{M}=9.5, \mathrm{SD}=0.503)$ and their two classroom teachers from the "Mustafa Bakija" primary school, from Gjakova, Kosovo. The sampling was purposeful.

\section{Results}

In order to examine the impact of intervention method of reading comprehension strategies in solving mathematical word problems by students, the results from pretest and posttest were analyzed statistically and teachers' reflective diaries are analyzed by using the content analyses. A paired sample t-test was conducted to compare student's scores in pretest before the intervention and after intervention on reading comprehension strategies. Results showed that students in both classes achieved better results in posttest comparing the pretest after intervention method for improving reading comprehension. In Table 1 are presented the basic statistics for the pretest and the post-test.

Table 1. Results from pretest and posttest.

Pretest Posttest

\begin{tabular}{lcccc}
\hline & Mean & SD & Mean & SD \\
\hline Class IV A & 2.38 & 1.98 & 3.88 & 3.16 \\
Class IV B & 3.0 & 1.81 & 4.46 & 2.14
\end{tabular}


The t-test was utilized in order to compare the results of the pre-test and the post-test. There was a significant difference from pretests to posttests in the scores of pretests for class IV A (M= 2.38, $\mathrm{SD}=1.98$ and posttest $(\mathrm{M}=3.88, \mathrm{SD}=3.16), \mathrm{t}(25)=-4.431, \mathrm{p}=.000$ in the class $\operatorname{IVB}(\mathrm{M}=3.0, \mathrm{SD}=1.81$ and posttest $\mathrm{M}=4.46, \mathrm{SD}=2.14), \mathrm{t}(23)=-8.085, \mathrm{p}=.000$ respectively).

Results have shown the significant improvement of student's skills for mathematics word problem-solving in both classes IVA and IV B after the intervention program for reading comprehension.

From the reflection from teacher's diaries, it was found out that one of the main reasons why students struggle during mathematical word problem solving is the difficulty to comprehend the text within the words. The intervention for reading comprehension has a positive effect for supporting students to improve their word problem-solving skills.

Before it was noticed that students don't understand the text within the word problem. There were some keywords and expressions which make students confused when they read a text or a word problem. Sometimes, the words are not familiar with them. But using reading comprehension strategies was helpful for the students to get a better meaning of the text they read as the main step to solve the word any word problem.

(Teacher A)

When students read the word problem some of them get the partial meaning of what they read. It was helpful for students to use reading comprehension strategies in small groups because they felt more comfortable when they collaborate with each other. I see that there was a significant improvement in students' word problem skills.

(Teacher B)

\section{Discussion and conclusions}

This study investigated the impact of reading comprehension for improving student's skills for mathematics word problem-solving. The results from the study shown that the use of reading comprehension strategies impact reading comprehension and have a positive effect on improving student's skills for mathematical word problem-solving. The reading comprehension strategies enabled student's clearer meaning and comprehension of the word problems. Students after receiving the instruction of reading comprehension strategies achieved better results in mathematical word problem-solving. This finding is supported by earlier studies (Vilenius-Tuohimaa et al., 2008; Özsoy, Kuruyer, Çakiroglu, 2015) which showed the relation between reading comprehension and mathematical word problem-solving.

The results from the study confirmed that students improve their comprehension when they work through comprehension strategies in groups, they clarified the misunderstanding content of the word problem and unclear expressions, they generate questions for better comprehension of the text they read and summarized their understanding. Therefore, when students improve their reading comprehension, they can perform better outcomes in mathematical word problem-solving. From this, it can be concluded that teachers should use the reading comprehension strategies in their classes. They should work for improving student's reading comprehension to achieve better results in mathematical word problem solving, and they can do this in cooperation with each other. Finally, different students have different needs, thus it is suggested that other approaches to word problem solving should take into consideration.

\section{References}

Boonen, A. J. H., De Koning, B., B., Jolles, J., Van der Schoot, M. (2016). Word Problem Solving in Contemporary Math Education: A Plea for Reading Comprehension Skills Training. Frontiers in Psychology. Volume 7:191.

Burns, M. (2007). About Teaching Mathematics. Sausalito, CA. Math Solution Publications.

Capraro, M. R., Capraro, M.M., \& Rupley, H.W. (2012). Reading-enhanced word problem solving: a theoretical model. European Journal of Psychology of Education 27, 91-114

Creswell, J. W. (2012). Educational Research Planning, Conducting and Evaluating Quantitative and Qualitative Research. (4th ed.) Boston. Pearson Education, Inc

Daroczy, G., Wolska, M., Meurers, D. W., \& Nuerk, H. (2015). Word problems: a review of linguistic and numerical factors contributing to their difficulty. Frontiers in Psychology. Volume 6:348.

James, E.A., Milenkiewicz, M.T., Bucknam, A. (2008). Participatory Action Research for Educational Leadership:Using Data-Driven Decision Making to Improve Schools. California. Sage Publications. 
Jitendra, A. K., Griffin, C. C., Deatline-Buchman, A., \& Sczesniak, E. (2007). Mathematical word problem-solving in third-grade classrooms. Journal of Educational Research, 100, 283-302.

Özsoy, G. \& Kuruyer H. G. \& Çakiroğlu, A. (2015). Evaluation of Students' Mathematical Problem-Solving Skills in Relation to Their Reading Levels. International Electronic Journal of Elementary Education, 8(1), 113-132. Polya, G. (1957). How to Solve It. New Jersey. Princeton University Press.

Palincsar, A.S. \& Brown, A. L. (1986). Interactive Teaching to Promote Independent Learning from Text. The Reading Teacher. Vol.39, No.8, pp. 771-777

Pearce, D. L., Bruun, F., Skinner, K., Lopez-Mohler, C. (2013). What teachers say about student difficulties solving mathematical word problems in grades 2-5International Electronic Journal of Mathematics Education, Vol.8, No.1

Vilnius-Tuohimaa, M. P., Aunola, K., \& Nurmi, J. E. (2008). The Association Between Mathematical Word Problems and Reading Comprehension. Educational Psychology, 28(4), 409-426.

Vula, E., Avdyli, Rr., Berisha, V., Saqipi, B., Elezi, Sh., (2017). The impact of metacognitive strategies and self-regulating processes of solving math word problems. International Electronic Journal of Elementary Education, 10(1), 49-59.

Zhu, N. (2015). Cognitive Strategy Instruction for Mathematical Word Problem-solving of Students with Mathematics Disabilities in China. International Journal of Disability, Development, and Education, 2015 Vol. 62, No. 6, 608-627. 